Studia Judaica 19 (2016), nr 2 (38), s. 251-273

doi:10.4467/24500100STJ.16.012.6223

Stefan Gąsiorowski

\title{
Obraz Żydów w siedemnasto- i osiemnastowiecznych kronikach klasztornych z terenów Rzeczypospolitej na wybranych przykładach
}

\author{
THE PORTRAYAL OF JEWS IN SEVENTEENTH- AND EIGHTEENTH-CENTURY \\ MONASTERY CHRONICLES FROM THE POLISH-LITHUANIAN COMMONWEALTH \\ ON THE BASIS OF SELECTED EXAMPLES
}

\begin{abstract}
Monastery chronicles from the Polish-Lithuanian Commonwealth provide valuable insight not only into the history of individual orders and the Polish clergy in general, but also into the history of mentality, daily life and religious and ethnic minorities. Although references to Jews are rather sporadic in such chronicles, they are nevertheless quite diverse and concern almost all aspects of Jewish activity in Poland and abroad. Therefore, they can serve as an excellent complement to other sources in the field, including Jewish ones, and those of various secular institutions and offices. It should be noted, however, that the credibility of the information contained in monastery chronicles is always dependent on the distance in time and space between the chronicler and the described events and should - if possible-be verified against other documentary sources from the same period.
\end{abstract}

Keywords: monastery chronicles, converts, host desecration, ritual murders, tenants.

Słowa kluczowe: kroniki klasztorne, konwertyci, profanacja hostii, mordy rytualne, dzierżawcy.

Na wstępie artykułu warto przypomnieć, że zapiski kronikarskie były prowadzone w klasztorach na ziemiach polskich od czasów najdawniejszych, pierwotnie w formie roczników na marginesach kalendarzy, a następnie rozrastały się do bardziej pojemnych form pisarskich, jak właśnie kroniki 
czy diariusze. Miały one różną zawartość, która z biegiem lat ulegała rozszerzeniu o nowe działy czy tematy. Zwykle prócz dokumentów fundacyjnych i uposażeniowych zamieszczano w nich spisy przełożonych klasztoru, dobrodziejów i zmarłych zakonników czy sióstr, inwentarze skarbca, archiwum, biblioteki itp. oraz notki o wydarzeniach w klasztorze i w świecie zewnętrznym. Kroniki te spisywali zazwyczaj przełożeni klasztoru lub specjalnie z grona ojców czy sióstr danego konwentu wybrani kronikarze, których nazywano chronologami ${ }^{1}$.

\section{Kroniki klasztorne jako źródło historyczne}

Kroniki klasztorne były przeznaczone wyłącznie na użytek własny tychże klasztorów, czyli tzw. domowy. Łączy się z tym ważna konstatacja, że zapisywano tam wszystkie istotne dla danej społeczności zakonnej wydarzenia, a nie tylko te, które przedstawiały ją w samych pięknych barwach². Dlatego wydaje się, że kroniki klasztorne, podobnie jak dokumenty urzędowe i przywileje, należy uznać za wiarygodne źródło historyczne, zwłaszcza jeśli spisywano je na bieżąco, co wszak nie było regułą.

Kroniki klasztorne zawierają wiele wiadomości odnoszących się zarówno do życia zakonnego, jak i innych kwestii dotyczących spraw politycznych, kulturalnych, obyczajowych, mentalności itd., a nawet tematyki żydowskiej. Do naszych czasów zachowało się niemało tego typu źródeł rękopiśmiennych, które nadal nie są dostatecznie zbadane przez historyków, a już na pewno nie korzystają z nich judaiści. Związane jest to zapewne z trudnym dostępem do tych kronik, które są przechowywane $\mathrm{w}$ archiwach klasztornych nie zawsze w pełni zinwentaryzowanych, rzadko w całości udostępnianych szerokiemu gronu uczonych. Archiwa klasztorów skasowanych w XIX w. zostały przekazane do zbiorów państwowych, często jednak w okrojonej postaci z powodu różnych zniszczeń. Oczywiście wiele kronik uległo destrukcji na skutek licznych kataklizmów, które nawiedzały ziemie polskie w ciągu wieków, żeby wspomnieć jedynie o dwóch wojnach światowych. Jednakże duża część kronik klasztornych zachowała się do czasów obecnych: jedne w rękopisach, inne w druku, od końca XIX w. zaczęto je bowiem sukcesywnie wydawać - z przerwą na okresy wojen

${ }^{1}$ Hieronim Eugeniusz Wyczawski, Przygotowanie do studiów w archiwach kościelnych, Kalwaria Zebrzydowska 1989, s. 305-306.

${ }^{2}$ Małgorzata Borkowska, Łatanie pamięci, czyli rzecz o klasztornym kronikarstwie retrospektywnym, „Znak” 480 (1995), s. 109. 
i w zasadzie czasy PRL-u. Zwyczaj ten został wznowiony po 1989 r., a na wielką skalę - od 2000 r. Na tle publikacji tego typu wyróżniają się Kroniki Staropolskie, seria ogłaszana drukiem przez poznańskie Wydawnictwo Miejskie. Jak dotąd, kilka wydanych kronik klasztornych, szczególnie tych z przełomu XIX i XX w., zostało już również zdigitalizowanych³ ${ }^{3}$.

Na temat kronikarzy oraz kronik klasztornych i ich zawartości ukazało się stosunkowo niewiele publikacji. Wśród nich na szczególną uwagę zasługują prace Karola Górskiego, s. Małgorzaty Borkowskiej i Karoliny Targosz. Ta ostatnia autorka w książce Piórem zakonnicy. Kronikarki w Polsce XVII w. o swoich zakonach $i$ swoich czasach (Kraków 2002) zawarła informacje zaczerpnięte z żeńskich kronik klasztornych, w szczególności dotyczące również tematyki żydowskiej. Z tego typu źródeł korzystał także Waldemar Kowalski w swoich licznych artykułach o konwersjach żydowskich na katolicyzm ${ }^{4}$. Wbrew pozorom, mimo że dosyć liczne grono uczonych w Polsce i za granicą zajmowało się problematyką relacji chrześcijańsko-żydowskich w dawnej Rzeczypospolitej, tylko niewielu z nich korzystało przy pisaniu swoich dzieł z zachowanych kronik klasztornych. Należą do nich m.in. Adam Kaźmierczyk ${ }^{5}$ czy Magda Teter ${ }^{6}$. Wielu innych nie uwzględniło tego typu źródeł w swoich pracach, w tym Jakub Goldberg, Judith Kalik, Krzysztof Modelski czy Bogdan Rok?

${ }^{3}$ Np.: Ks. Jana Wielewickiego Dziennik spraw domu zakonnego OO. Jezuitów u św. Barbary w Krakowie od r. 1579 do r. 1599, Czcionkami Drukarni c.k. Uniwersytetu Jagiellońskiego, Kraków 1881, s. VIII, 273; www.dbc.wroc.pl/dlibra/documentadata?id=6729\&from= publication [dostęp: 16 września 2014].

${ }^{4} \mathrm{~Np}$. Waldemar Kowalski, Stopnicki rejestr konwertytów XVII-XIX w., „Nasza Przeszłość" 76 (1991), s. 194-195, 202, 208.

5 Adam Kaźmierczyk, Converted Jews in Kraków, 1650-1763, „Gal-Ed” 21 (2007), s. 19, 27-28, 36, 40, 42-43; tenże, Rodzitem się Żydem... Konwersje Żydów w Rzeczypospolitej XVII-XVIII wieku, Kraków 2015.

${ }^{6}$ Jakkolwiek częściej powołuje się na odnalezione konstytucje synodów biskupich, listy pasterskie różnych prałatów, a czasem nawet na kronikę zboru luterańskiego. Magdalena Teter, Jewish Conversions to Catholicism in the Polish-Lithuanian Commonwealth of the Seventeenth and Eighteenth Centuries, „Jewish History” 17 (2003), s. 257-283; taż, The Legend of Ger Zedek of Wilno as Polemic and Reassurance, „AJS Review” 29 (2005), nr 2, s. 237263; taż, Sinners on Trial: Jews and Sacrilege after the Reformation, Cambridge-London 2011. W tym miejscu dziękuję profesor Magdzie Teter za udostępnienie wielu swoich prac.

7 Jakub Goldberg, Poles and Jews in the 17th and 18th Centuries: Rejection or Acceptance, „Jahrbücher für Geschichte Osteuropas” 40 (N.F. 22) (1974), s. 248-282; tenże, Żydowscy konwertyci w społeczeństwie staropolskim, [w:] Społeczeństwo staropolskie. Studia i szkice, t. 4, red. Anna Izydorczyk, Andrzej Wyczański, Warszawa 1986, s. 195-247; tenże, Kilkakrotny chrzest żydowskiego konwertyty, [w:] Religie, edukacja, kultura. Księga pamiątkowa dedykowana Profesorowi Stanistawowi Litakowi, red. Marian Surdacki, Lublin 2002, s. 91-95; Judith Kalik, Patterns of Contacts between the Catholic Church and the Jews in the Polish-Lithuanian Commonwealth: The Jewish Debts, [w:] Studies in the History of the Jews 


\section{Tematyka żydowska w kronikach klasztornych}

W niniejszym artykule zajmuję się tematyką żydowską zawartą w około dwudziestu kronikach klasztornych różnych proweniencji zakonnych z terenów dawnej Rzeczypospolitej; kroniki te zostały spisane w języku łacińskim i polskim w XVII i XVIII w., a wydane drukiem od końca XIX do początku XXI w. Odnoszą się one do dziejów benedyktynek, bernardynek i bernardynów, brygidek, dominikanek, jezuitów, karmelitanek i karmelitów bosych, karmelitów trzewiczkowych, klarysek, norbertanek i reformatów zamieszkałych w klasztorach wzniesionych na terenie Małopolski (Imbramowice, Kraków, Lublin, Radom, Sandomierz), Wielkopolski (Poznań), Mazowsza (Warszawa), Litwy (Grodno, Wilno) i Rusi (Lwów). Objętość poszczególnych kronik wynosi od kilkunastu do prawie 500 stron. Częstość wzmianek odnoszących się do Żydów jest w nich zróżnicowana - czasem jest zerowa, lecz zdarza się, że zapiski pojawiają się na co drugiej stronie (w jednym przypadku). W sumie jednak w większości kronik klasztornych temat ten występuje raczej marginalnie ${ }^{8}$.

in Old Poland in Honor of Jacob Goldberg, red. Adam Teller, Jerusalem 1998, s. 102-122; Krzysztof Modelski, Conversion as a Problem of Rational Choice, [w:] Studies in the History..., s. 147-160; Bogdan Rok, Stosunek polskiego Kościoła katolickiego do sprawy żydowskiej w I połowie XVIII wieku, [w:] Z historii ludności żydowskiej w Polsce i na Ślasku, red. Krystyn Matwijowski, Wrocław 1994, s. 85-97.

${ }^{8}$ Akta klasztoru pp. Franciszkanek s. Jędrzeja w Krakowie elekcyi ksień i innych potocznych dziejów tegoż klasztoru składajace się od r. 1784-go [do r. 1850], Archiwum SS. Klarysek w Krakowie, sygn. A 37; Jan Wielewicki, Dziennik spraw domu zakonnego OO. Jezuitów u ś. Barbary w Krakowie od r. 1579 do r. 1599 (włącznie), [t. 1], Kraków 1881 (Scriptores Rerum Polonicarum. Tomus septimus); tenże, Dziennik spraw domu zakonnego OO. Jezuitów u św. Barbary w Krakowie od r. 1600 do r. 1608 (włącznie), [t. 2], Kraków 1886 (Scriptores Rerum Polonicarum. Tomus decimus); tenże, Dziennik spraw domu zakonnego OO. Jezuitów u św. Barbary w Krakowie od r. 1609 do r. 1619 (wtącznie), [t. 3], Kraków 1889 (Scriptores Rerum Polonicarum. Tomus decimus quartus); tenże, Dziennik spraw domu zakonnego OO. Jezuitów u św. Barbary w Krakowie od r. 1620 do r. 1629 (wtącznie), t. 4, Kraków 1899 (Scriptores Rerum Polonicarum. Tomus decimus septimus); Rozbiór rękopiśmiennej księgi: Zapisy Karmelitanek Bosych we Lwowie, wyd. Izydor Szaraniewicz, „Przewodnik Naukowy i Literacki”, R. 13, t. 13 (1885), z. 5, s. 403-411; z. 6, s. 495-509; z. 7, s. 591-604; [Rafał Józef Kalinowski], Klasztory Karmelitanek Bosych w Polsce, na Litwie i Rusi. Ich początek, rozwój i tułactwo w czasie rozruchów wojennych w XVII wieku. Rzecz osnuta na kronikach klasztornych, t. 1, Kraków 1902; Kronika klasztoru Panien Bernardynek warszawskich, wyd. Stanisław Chodyński, „Kwartalnik Teologiczny” 6 (1907), z. 1-4, s. 38-90; Zapiski historyczne benedyktynek radomskich oraz materiaty do kultu Magdaleny Mortęskiej, oprac. Anna Małgorzata Borkowska, [w:] Karol Górski, Anna Małgorzata Borkowska, Historiografia zakonna a wzorce świętości w XVII w., Warszawa 1984, s. 321; Dzieje kapitularne zakonnic świętej matki Brygitty konwentu grodzieńskiego, oprac. Małgo- 
W przejrzanych kronikach pojawiła się różnorodna tematyka odnosząca się do Żydów, określanych tam często jako niewierni. Zdecydowanie jednak przeważają wzmianki dotyczące ich konwersji. W mniejszym zakresie przekazano informacje o przypadkach rzekomych mordów rytualnych i profanacji hostii, wiadomości natury gospodarczej czy wydarzenia niecodzienne powiązane z Żydami, jak różne kataklizmy, kradzieże, bójki, zbrodnie, tumulty i przechody obcych wojsk. Poruszono w nich także kwestie natury religijnej, moralnej i obyczajowej. Stosunkowo najmniej miejsca poświęcono w kronikach żydowskim budynkom, ulicom czy cmentarzom, a także rozprawom sądowym.

\section{Konwertyci}

Jak wspomniano, Żydzi zostali odnotowani w kronikach klasztornych głównie jako konwertyci. Wzmianki o ich chrzcie zawarto w sześciu z omawianych ksiąg. Najczęściej są to krótkie informacje dotyczące daty

rzata Borkowska, Krzysztof Obremski, Toruń 2001; Kroniki Benedyktynek poznańskich, oprac. Małgorzata Borkowska, Wanda Karkucińska, Jacek Wiesiołowski, Poznań 2001; Kronika poznańskich Karmelitów Bosych, oprac. Piotr Franciszek Neumann, Poznań 2001; Kroniki Bernardynów poznańskich, oprac. Salezy Bogumił Tomczak, Jacek Wiesiołowski, Poznań 2002; Kronika bernardynek świętomichalskich w Wilnie, wyd. Maria Kałamajska-Saeed, „Nasza Przeszłość” 101 (2004), s. 331-435; Kronika jezuitów poznańskich (młodsza), t. 1: 1570-1653, oprac. Ludwik Grzebień, Jacek Wiesiołowski, Poznań 2004; Kroniczka rezydencji Karmelitów Trzewiczkowych w Poznaniu przy kościele Najświętszej Krwi Pana Jezusa na ul. Żydowskiej, oprac. Jacek Wiesiołowski, Poznań 2005; Kronika Benedyktynek Sandomierskich czyli Dzieje klasztoru sandomierskiego od roku 1615. 30 października. Spisane w roku 1763 za przetożeństwa P. Maryanny Siemianowski ksieni 13, t. 1, oprac. Anna Szylar, Sandomierz 2005; Kronika Reformatów poznańskich, oprac. Jacek Wiesiołowski, Salezy Bogumił Tomczak, Grzegorz Antoni Wiśniowski, Poznań 2006; Kronika fundacyjna klasztoru mniszek zakonu kaznodziejskiego na Gródku w Krakowie (1620-1639). „Kronika abo opisanie postępków i zachodów około fundowania konwentu”, wstęp i oprac. Anna Markiewicz, Kraków 2007; Jan z Komorowa, Krótka Kronika Zakonu Braci Mniejszych. Cz. 1, tłum. Kazimierz Żuchowski, „Przegląd Kalwaryjski” 11-12 (2007/2008), s. 297-406; tenże, Krótka Kronika Zakonu Braci Mniejszych. Cz. 2 (1453-1517), tłum. Kazimierz Żuchowski, „Przegląd Kalwaryjski” 13 (2009), s. 429-591; tenże, Krótka Kronika Zakonu Braci Mniejszych. Cz. 3 (1517-1536), thum. Kazimierz Żuchowski, „Przegląd Kalwaryjski” 14 (2010), s. 379-480; Kronika bernardynek lubelskich 1618-1885, wyd. Anna Szylar, Lublin 2009; Kronika Ojca Cypriana Damirskiego OFM, tłum. Kazimierz Żuchowski, „Przegląd Kalwaryjski” 15 (2011), s. 367-490; Metryka brygidek lubelskich, wstęp i oprac. Jarosław R. Marczewski, Lublin 2011; Zofia Grothówna, Kronika klasztorna sióstr norbertanek w Imbramowicach 1703-1741, wyd. Włodzimierz Bielak, Waldemar Żurek, Kielce 2011; Kronika Klasztoru Karmelitanek Bosych pw. św. Józefa w Lublinie, oprac. Czesław Gil, Poznań 2012. 
ceremonii, nowego imienia lub imion neofity, jego wieku, nazwiska świadków i kapłana, czasem też liczby obecnych wiernych, kleru i dostojnych gości. Zdarzają się także bardzo krótkie zapiski odnotowujące jedynie fakt chrztu wyznawcy judaizmu bez podania jakichkolwiek bliższych danych, typu: „Ochrzciliśmy [...] pewnego Żyda, skoro tylko pouczyliśmy go wyczerpująco o tajemnicach wiary"9. Znacznie dłuższe opisy, przedstawiające nie tylko samą ceremonię chrztu, ale również długą drogę do niego, dotyczą zwykle zdarzeń, w których mamy do czynienia z jakimś spektakularnym nawróceniem. Do tej kategorii należał zapewne, opisany pod rokiem 1788 w kronice reformatów poznańskich, chrzest Idy, córki Abrama, rabina poznańskiego. Była ona żoną Jakuba, syna Józefa, melameda z Królewca. Związek ten, zawarty w Kobylinie, trwał 15 lat, a jego owocem było czworo dzieci - trzech synów i jedna córka. Mieszkali w dzielnicy żydowskiej w Śródce pod Poznaniem (od $1800 \mathrm{r}$. część tego miasta), skąd Ida uciekła, chcąc przyjąć chrzest. Początkowo schroniła się u mieszczanek śródeckich, tercjarek, panien Aleksandry i Petronelli Boińskich, które przekazały ją pod opiekę ojców reformatów - Bartłomieja Żołądkiewicza i Elzeariusza Albrechta. Ci przez siedem tygodni uczyli ją zasad nowej wiary, po czym została ochrzczona przez o. gwardiana tegoż konwentu poznańskiego. $\mathrm{Na}$ chrzcie w oratorium św. Filipa Neri otrzymała imiona Brygida Tekla w obecności chrzestnych rodziców: Sebastiana Mejerera, ławnika i radnego poznańskiego, który w imieniu burmistrza nadał jej nazwisko Michalska. Odnotowana jest także obecność Zuzanny Barańskiej, Norberta Rozego, Marianny Smolińskiej, Nepomucena Kaczkiewicza, Agaty Kulerówny, Antoniego Kaczkiewicza i Reginy Żołądkiewiczówny oraz „zgromadzonego ludu”. Chrzestni ofiarowali jej na utrzymanie 607 złotych polskich ${ }^{10}$.

W kronice benedyktynek sandomierskich można przeczytać o innym chrzcie, który przebiegał w dramatycznych okolicznościach. Otóż 28 sierpnia 1763 r. do klasztoru benedyktynek w Sandomierzu przyprowadzono kilkuletnie dziecko żydowskie, zapewne w celu jego ochrzczenia. Na wieść o tym miejscowi Żydzi nalegali na ksienię Mariannę Siemianowską, aby im dziecko zwrócono, wskazując na jego młody wiek. Ksieni nie chciała tego uczynić i zamiast Żydom przekazała najpierw dziecko nieznanej z imienia kobiecie w miejscowej gorzelni, a następnie w nocy

\footnotetext{
${ }^{9}$ Kronika jezuitów poznańskich..., s. 16. Podobne lakoniczne wzmianki o chrztach Żydów można znaleźć: tamże, s. 59, 61, 142, 148.

${ }^{10}$ Kronika Reformatów poznańskich..., s. 175-176.
} 
zaprowadzono je do tamtejszego klasztoru ojców reformatów. Czyn ten oczywiście oburzył Żydów, którzy nadal domagali się zwrotu chłopca. Jednakże zgodnie z nakazem niewymienionego z nazwiska księdza kustosza koronnego ${ }^{11}$, który zasiadał w kapitule, zarządzono, że ponieważ dziecko żydowskie jest za małe, aby samo mogło się wypowiadać w kwestii wiary, należy więc uformować dwa kordony - w jednym mieli stać Żydzi, w drugim zaś katolicy; ustalono, że dziecko zostanie przekazane tej stronie, w którą się zwróci. Okazało się, że mimo namowy ojca dziecko zwróciło się w stronę katolików i zostało oddane na naukę ojcom reformatom. Należy przypuszczać, że tegoż żydowskiego chłopca, któremu nadano imiona Michał Józef Antoni, ochrzczono następnie 20 stycznia 1764 r. w kościele benedyktynek w Sandomierzu. Chrztu udzielił podkustosz Jan Nepomucen Radwański, a rodzicami chrzestnymi byli, w pierwszej parze, ksieni benedyktynek Marianna Siemianowska i bliżej nieznany podskarbi koronny, niejaki Masalski ${ }^{12}$.

Z odnalezionych w kronikach klasztornych 44 odnotowań chrztów z lat 1576-1796 dotyczących osób pochodzenia żydowskiego w przedziale wiekowym od 7 do 79 lat wynika, że 17 odnosiło się do mężczyzn, 10 do kobiet, 17 do dzieci (w tym 10 chłopców i 7 dziewczynek). W tym zestawieniu zachowało się 14 imion kobiet i dziewcząt (z których aż dziewięciu nadano imię Marianna) oraz tylko 6 imion mężczyzn i chłopców. Spis tych imion zamieszczono tu w dwóch oddzielnych tabelach z podziałem na Żydówki (tabela 1) i Żydów (tabela 2). Co ciekawe, znany jest też wiek wszystkich siedmiu ochrzczonych dziewcząt, a mianowicie: 7, 11, 12, 13 i dwie po 15 lat (jakkolwiek te dwie ostatnie osoby, a może nawet cztery, powinniśmy według ówczesnej nomenklatury traktować już jako kobiety). Wiek jednej z tych dziewczyn określono jedynie jako „kilkanaście lat”"13.

${ }^{11}$ Chodzi zapewne o Jana Nepomucena Radwańskiego, który od 1753 r. sprawował funkcję podkustosza, a od 1769 r. - archidiakona i oficjała sandomierskiego.

${ }^{12}$ Kronika Benedyktynek Sandomierskich..., s. 48, 56.

13 Tamże, s. 46-47, 53, 56, 69-71, 107-108, 121-122, 124, 141, 144; Kronika jezuitów poznańskich..., s. 16, 40-41, 59, 61, 115, 142, 148, 153, 286, 310-311, 316, 336; Kronika poznańskich Karmelitów Bosych..., s. 19; Kronika Reformatów poznańskich..., s. 175, 179-180, 183-184, 189-190; Grothówna, Kronika ..., s. 55-56, 209; Wielewicki, Dziennik spraw domu zakonnego OO. Jezuitów..., t. 4, s. 313, 329; Zapiski historyczne benedyktynek radomskich..., s. 321. 
Tabela 1. Spis imion ochrzczonych Żydówek występujących w przebadanych kronikach klasztornych (w kolejności chronologicznej)

\begin{tabular}{|c|c|c|c|c|c|}
\hline Lp. & $\begin{array}{c}\text { Imię żydowskie } \\
\text { lub przed } \\
\text { chrztem }\end{array}$ & $\begin{array}{c}\text { Imię/imiona } \\
\text { i nazwisko } \\
\text { chrześcijańskie }\end{array}$ & $\begin{array}{l}\text { Miejsce } \\
\text { chrztu }\end{array}$ & $\begin{array}{l}\text { Data } \\
\text { chrztu }\end{array}$ & Źródło \\
\hline 1 & $\begin{array}{c}\text { Anna } \\
\text { [hebr. Chana] }\end{array}$ & Marianna & Radom & $\begin{array}{l}9 \text { paździer- } \\
\text { nika } 1707\end{array}$ & $\begin{array}{l}\text { Zapiski historyczne } \\
\text { benedyktynek } \\
\text { radomskich, s. } 321 .\end{array}$ \\
\hline 2 & & $\begin{array}{c}\text { Katarzyna Helena } \\
\text { Czajowska } \\
\text { (z Czajowic) }\end{array}$ & $\begin{array}{l}\text { Imbramo- } \\
\text { wice }\end{array}$ & $\begin{array}{c}16 \text { maja } \\
1712\end{array}$ & $\begin{array}{c}\text { Grothówna, } \\
\text { Kronika, s. 55-56. }\end{array}$ \\
\hline 3 & & Zofia & Radom & 1714 & $\begin{array}{c}\text { Zapiski historyczne } \\
\text { benedyktynek } \\
\text { radomskich, s. } 321 .\end{array}$ \\
\hline 4 & & $\begin{array}{l}\text { Anna Justyna } \\
\text { z browaru } \\
\text { rzeżuskiego }\end{array}$ & $\begin{array}{l}\text { Imbramo- } \\
\text { wice }\end{array}$ & $\begin{array}{c}7 \text { sierpnia } \\
1727\end{array}$ & $\begin{array}{c}\text { Grothówna, } \\
\text { Kronika, s. } 209 .\end{array}$ \\
\hline 5 & & Marianna & $\begin{array}{c}\text { Skórzewo, } \\
\text { pow. } \\
\text { poznański }\end{array}$ & 1748 & $\begin{array}{l}\text { Kronika Reforma- } \\
\text { tów poznańskich, } \\
\text { s. } 179 . \\
\end{array}$ \\
\hline 6 & & $\begin{array}{l}\text { Marianna } \\
\text { Urszula }\end{array}$ & Sandomierz & $\begin{array}{c}26 \text { lipca } \\
1763\end{array}$ & $\begin{array}{l}\text { Kronika Benedyk- } \\
\text { tynek Sandomier- } \\
\text { skich, s. 46-47. }\end{array}$ \\
\hline 7 & & $\begin{array}{l}\text { Marianna Apo- } \\
\text { lonia } \\
\end{array}$ & Sandomierz & $\begin{array}{l}18 \text { grudnia } \\
1763\end{array}$ & Tamże, s. 53. \\
\hline 8 & & $\begin{array}{c}\text { Marianna } \\
\text { z Rzeczycy }\end{array}$ & Sandomierz & $\begin{array}{c}2 \text { listopada } \\
1764 \\
\end{array}$ & Tamże, s. 69-70. \\
\hline 9 & & $\begin{array}{l}\text { Marianna } \\
\text { z Ossolina }\end{array}$ & Sandomierz & $\begin{array}{c}14 \text { listo- } \\
\text { pada } 1764\end{array}$ & Tamże, s. 69, 71. \\
\hline 10 & & $\begin{array}{l}\text { Marianna Schola- } \\
\text { styka z Łagowa }\end{array}$ & Sandomierz & $\begin{array}{c}25 \text { marca } \\
1767\end{array}$ & Tamże, s. 107-108. \\
\hline 11 & & $\begin{array}{c}\text { Konstancja } \\
\text { Józefa } \\
\text { Wojciechowska }\end{array}$ & Sandomierz & $\begin{array}{c}27 \text { stycznia } \\
1769\end{array}$ & Tamże, s. 121-122. \\
\hline 12 & & $\begin{array}{c}\text { Marianna Kune- } \\
\text { gunda Franciszka } \\
\text { z Garbacza } \\
\end{array}$ & Sandomierz & $\begin{array}{l}30 \text { lipca } \\
1769\end{array}$ & Tamże, s. 124. \\
\hline 13 & & Marianna & $\begin{array}{l}\text { Bidziny, } \\
\text { pow. opa- } \\
\text { towski }\end{array}$ & $\begin{array}{c}28 \text { września } \\
1771\end{array}$ & Tamże, s. 141, 144. \\
\hline 14 & $\begin{array}{c}\text { Ida } \\
\text { [hebr. Jehudit] } \\
\text { Abramówna } \\
\text { [córka Abrama] }\end{array}$ & $\begin{array}{c}\text { Brygida Tekla } \\
\text { Michalska }\end{array}$ & Poznań & $\begin{array}{c}28 \text { września } \\
1788\end{array}$ & $\begin{array}{l}\text { Kronika Reforma- } \\
\text { tów poznańskich, } \\
\text { s. } 175-176 .\end{array}$ \\
\hline
\end{tabular}


Tabela 2. Spis imion ochrzczonych Żydów występujących w przebadanych kronikach klasztornych (w kolejności chronologicznej)

\begin{tabular}{|c|c|c|c|c|c|}
\hline Lp. & $\begin{array}{c}\text { Imię } \\
\text { żydowskie }\end{array}$ & $\begin{array}{c}\text { Imię/imiona } \\
\text { i nazwisko } \\
\text { chrześcijańskie }\end{array}$ & $\begin{array}{l}\text { Miejsce } \\
\text { chrztu }\end{array}$ & $\begin{array}{l}\text { Data } \\
\text { chrztu }\end{array}$ & Źródło \\
\hline 1 & & Michał & Poznań & $\begin{array}{c}8 \text { grudnia } \\
1623\end{array}$ & $\begin{array}{l}\text { Kronika poznań- } \\
\text { skich Karmelitów } \\
\text { Bosych, s. } 19 .\end{array}$ \\
\hline 2 & $\begin{array}{l}\text { Lewkowicz [syn } \\
\text { Jehudy-Lejba] }\end{array}$ & Michał & Kraków & $\begin{array}{c}9 \text { września } \\
1629\end{array}$ & $\begin{array}{l}\text { Wielewicki, Dzien- } \\
\text { nik spraw domu } \\
\text { zakonnego OO. } \\
\text { Jezuitów, t. 4, s. } 329 .\end{array}$ \\
\hline 3 & & Teodor Desau & Poznań & $\begin{array}{c}8 \text { stycznia } \\
1754\end{array}$ & $\begin{array}{l}\text { Kronika Reformatów } \\
\text { poznańskich, s. } 180 .\end{array}$ \\
\hline 4 & & $\begin{array}{l}\text { Michał Józef } \\
\text { Antoni }\end{array}$ & Sandomierz & $\begin{array}{c}20 \text { stycznia } \\
1764\end{array}$ & $\begin{array}{l}\text { Kronika Benedykty- } \\
\text { nek Sandomierskich, } \\
\text { s. } 56 .\end{array}$ \\
\hline 5 & & $\begin{array}{l}\text { Jan Marcin } \\
\text { Pruski }\end{array}$ & Poznań & $\begin{array}{c}11 \text { listopada } \\
1769\end{array}$ & $\begin{array}{l}\text { Kronika Reforma- } \\
\text { tów poznańskich, } \\
\text { s. } 183-184 .\end{array}$ \\
\hline 6 & $\begin{array}{l}\text { Beniamin Izrael } \\
\text { z Czarnkowa }\end{array}$ & $\begin{array}{l}\text { Szymon } \\
\text { Chęciński }\end{array}$ & Poznań & $\begin{array}{l}26 \text { paździer- } \\
\text { nika } 1796\end{array}$ & Tamże, s. 189-190. \\
\hline
\end{tabular}

W kontekście żydowskich konwersji warto też zwrócić uwagę na zapiskę w jednej z kronik poznańskich bernardynów, z której dowiadujemy się, że w 1751 r. Żydzi urządzili w Wilnie misje wśród chrześcijan, namawiając ich do przyjęcia judaizmu. W efekcie „trzy niewiasty chrześcijanki zwiedli i do Talmudu przyciągnęli" ${ }^{14}$.

\section{Zapiski o rzekomych profanacjach hostii}

Oprócz konwersji stosunkowo wiele wzmianek dotyczących Żydów zajmują w kronikach klasztornych tematy odnoszące się do rzekomych profanacji hostii i mordów rytualnych. Najwięcej znajduje się ich w kroniczce rezydencji karmelitów trzewiczkowych w Poznaniu, która została spisana w latach 1754-1769 pt. Diariusz Rezydencji Przenajświętszej Krwi Chrystusa przez kolejnych prezydentów tejże rezydencji, począwszy od o. Anastazego od św. Brokarda, lektora św. teologii, a skończywszy na o. Arnoldzie, syndyku prowincji wielkopolskiej. Wspomniana rezydencja jest ściśle związana z legendą autorstwa Jana Długosza dotyczącą hostii jakoby sprofanowanej

${ }^{14}$ Zaginiony rękopis kroniki domowej, [w:] Kroniki Bernardynów poznańskich..., s. 366. 
przez Żydów poznańskich i cudownie odnalezionej na błoniach w okolicy miasta w sierpniu 1399 r. Autorzy kolejnych wersji legendy starali się ją uwiarygodnić poprzez dodanie nowych szczegółów faktograficznych i topograficznych. W ten sposób w XVI w. wskazano jedną z kamienic przy ul. Żydowskiej w Poznaniu, gdzie jakoby dokonywano nakłuwania już nie jednej, lecz trzech hostii, z których tryskała krew. W połowie XVII w. karmelici uzyskali zgodę króla Jan Kazimierza na przekształcenie tej kamienicy w oratorium, a na początku XVIII w. powstał tam kościółek Najświętszej Krwi Chrystusa ${ }^{15}$.

Już na wstępie wspomnianego Diariusza znajduje się dwustronicowy tekst pt. Krótkie opisanie wzniesienia kaplicy Przenajświętszej Krwi Chrystusa Pana przy ulicy Żydowskiej w Poznaniu, w którym szczegółowo opisano świętokradztwo, jakie 15 sierpnia 1399 r. w kamienicy rodziny Świdwów rzekomo popełnili rabini nożami na trzech hostiach, a następnie przywołano kolejne dekrety kurii rzymskiej i biskupa poznańskiego Mikołaja Stanisława Święcickiego potwierdzające fakt profanacji i zezwalające na szczególny kult Bożego Ciała w tym miejscu ${ }^{16}$. W dalszej części kroniki czytamy o odnalezieniu przez rezydenta oratorium, o. Dionizego od św. Antoniego, studni, w której Żydzi mieli zatopić hostie. Studnia ta została oczyszczona i napełniona wodą, a chorzy pijący z jej zdroju wracali do zdrowia ${ }^{17}$. W 1730 r. kolejny przełożony kościółka, o. Bartłomiej od św. Adriana, przy okazji jego remontu polecił wymalować „,historię przebicia Przenajświętszej Hostii oraz egzekucji Żydów przez kata, razem ze świętokradczą niewiastą", która im hostie sprzedała. Fakt ten bardzo wzburzył miejscową gminę żydowską, która poprzez protekcję magnatów próbowała wpłynąć na karmelitów, aby usunęli to malowidło, ponieważ chłopi i wyrostki dopuszczali się z jego powodu ataków na Żydów. Jednakże prowincjał zakonu, o. Erazm, nie wyraził na to zgody. Co więcej, w połowie XVIII w. karmelici bosi ustalili, że co roku w piątek przed niedzielą, kiedy świętują dedykację poznańskiego kościoła katedralnego (czyli w drugiej połowie sierpnia), będą obchodzić „wspomnienie Przebicia Trzech Przenajświętszych Hostii”. W roku 1750 o. Arnold, syndyk prowincji wielkopolskiej, nakłonił miejscową gminę żydowską, ażeby z tej okazji - również corocznie - dostarczała karmelitom odpowiedniej ilości ryb i przypraw jako formy „karnej zapłaty za zbrodnię”, której jakoby

\footnotetext{
15 Jacek Wiesiołowski, Wstęp, [w:] Kroniczka rezydencji Karmelitów..., s. V-VII.

${ }^{16}$ Kroniczka rezydencji Karmelitów..., s. 1-11.

17 Tamże, s. 14.
} 
dokonali. Owo „wspomnienie” trwało przez oktawę i miało uroczysty charakter. Według omawianej kroniki było obchodzone co najmniej do 1768 r. Ponadto jeden z rezydentów kościółka, o. Paweł od św. Tomasza, około roku 1751 wzniósł przed nim portyk, dzięki czemu - jak podkreślono w tej kronice - Żydzi utracili okazję zaglądania do jego wnętrza ${ }^{18}$.

Wzmianki dotyczące opisanej wcześniej legendy oraz miejsca kultu trzech rzekomo sprofanowanych hostii, a także anonimowej pracy na ten temat, wydanej w formacie A4 pt. Hystorya o SS. Trzech Hostyach w Poznaniu, można znaleźć również w kronice reformatów poznańskich ${ }^{19}$. Z kolei w kronice jezuitów poznańskich pod rokiem 1571 wśród opowieści o podróży prowincjała tego zakonu o. Wawrzyńca Maggia wraz z o. Jakubem Wujkiem, o. Szymonem Wysockim i dwoma braćmi z Warszawy - gdzie podejmował ich nuncjusz apostolski Giovanni Francesco Commendone - zawarto passus, w którym czytamy, że „w drodze do Sochaczewa dowiedzieli się, że prawdą było to, co opowiadano wówczas o cudach dziejących się za przyczyną Najświętszej Eucharystii pokłutej przez Żydów, których zdradziła i o śmierć przyprawiła krew ociekająca obficie z podziurawionej Hostii" ${ }^{20}$. Jest to zapewne nawiązanie do wydarzeń, które miały miejsce właśnie w Sochaczewie w 1556 r. z oskarżenia wcześniejszego nuncjusza Alojzego Lippomana ${ }^{21}$.

\section{Wzmianki o rzekomych mordach rytualnych}

W wybranych kronikach klasztornych znajdują się również krótkie relacje dotyczące oskarżeń Żydów o mordy rytualne. Na przykład w kronice bernardynów autorstwa Jana z Komorowa widnieje krótka wzmianka o dramatycznych wydarzeniach w Lublinie w $1581 \mathrm{r}$. za sprawą kobiety, która rzekomo sprzedała swojego synka Żydom. Oni zaś mieli „przelać jego krew”. Wielu wówczas pochwycono Żydów, a jak dalej czytamy w kronice: „[ich] ofiary niech będą przebłaganiem Boga i ludzi”22. Interesujące, że - jak dotąd - jest to jedyna wzmianka dotycząca tego zdarzenia, ponieważ historycy zajmujący się tematem oskarżeń Żydów o rzekome

18 Tamże, s. 18-19, 23, 35, 52-53, 76, 146.

${ }^{19}$ Kronika Reformatów poznańskich..., s. 31, 32, 111.

${ }^{20}$ Kronika jezuitów poznańskich..., s. 9.

${ }^{21}$ O oskarżeniu i procesie w Sochaczewie w 1556 r. zob. m.in. Hanna Węgrzynek, „Czarna legenda” Żydów. Procesy o rzekome mordy rytualne w dawnej Polsce, Warszawa 1995, s. 51 i n., 182 i n.

22 Jan z Komorowa, Krótka Kronika Zakonu Braci Mniejszych. Cz. 3..., s. 473. 
mordy rytualne i profanacje hostii w dawnej Rzeczypospolitej nie odnotowali w ogóle omawianego wydarzenia. Istnieje też przypuszczenie, że w przytoczonej kronice chodzi raczej o zajścia, które były w Lublinie, ale 2 lata wcześniej lub też 11 lat potem, wiadome już z innych źródeł²3.

Dobrze znana jest sprawa procesu Żydów - z oskarżenia o mord rytualny $-\mathrm{z}$ lat $1736-1740 \mathrm{w}$ Poznaniu. Proces ten został odnotowany w dwóch kronikach klasztornych tamtejszych zakonów: karmelitów bosych i bernardynów, oraz szczegółowo opracowany przez historyków - Majera Bałabana, Josepha Perlesa, Zenona Guldona, Jacka Wijaczkę i Annę Michałowską-Mycielską. W obu kronikach informacje o tych wydarzeniach są bardzo lakoniczne, mogą jednak stanowić dopełnienie materiałów na ten temat zebranych w źródłach przez wspomnianych historyków - mimo błędnej daty (1735 r.) wydania oskarżenia w kronice bernardynów ${ }^{24}$.

\section{Działalność ekonomiczna Żydów}

W kronikach katolickich klasztorów można również znaleźć niemało wiadomości z zakresu ekonomicznej działalności Żydów, w tym o ich handlu, rzemiośle, operacjach pieniężnych, daninach na rzecz kościołów itd. Zapewne jako ciekawostkę w kronice poznańskich karmelitów bosych odnotowano pod rokiem 1755 fragment testamentu bogatego portugalskiego Żyda zwanego Pirita lub Pinta (być może jednak chodzi o przedstawiciela słynnej rodziny Pinto), który zmarł wówczas w Amsterdamie i pozostawił po sobie wielki majątek. W testamencie rozdzielił go różnym instytucjom świeckim, chrześcijańskim i żydowskim, a także biednym w Amsterdamie, Hadze i Jerozolimie oraz rodzinie i służbie. Przykładowo: holenderskie Stany Generalne otrzymały 500 tys. guldenów i dodatkowo półtora miliona na prowadzenie wojen, wszystkie kościoły/zbory chrześcijańskie w Hadze i Amsterdamie - 100 tys. guldenów,

${ }^{23}$ Joseph Perles, Geschichte der Juden in Posen, Breslau 1865, s. 82-84, 98-105; Węgrzynek, „Czarna legenda” Żydów..., s. 186; Zenon Guldon, Jacek Wijaczka, Procesy o mordy rytualne w Polsce w XVI-XVIII wieku, Kielce 1995, s. 34; Anna Michałowska, Między demokracja a oligarchia. Władze gmin żydowskich w Poznaniu i Swarzędzu (od połowy XVII do końca XVIII wieku), Warszawa 2000, s. 18.

${ }^{24}$ Kronika poznańskich Karmelitów Bosych..., s. 236; Kroniki Bernardynów poznańskich..., s. 276-277; Majer Bałaban, Arje Lejb Kalahora (Do procesu poznańskiego w latach 1736-1740), [w:] tenże, Studja historyczne, Warszawa 1927, s. 141-150; Perles, Geschichte der Juden ..., s. 82-84, 98-105; Guldon, Wijaczka, Procesy o mordy rytualne..., s. 69-70; Michałowska, Między demokracją a oligarchią..., s. 18. 
przełożeni miasta żydowskiego w Jerozolimie - milion, synagoga portugalska w Amsterdamie - półtora miliona, synagoga niemiecka - 15 tys., żona - trzy miliony oraz wszystkie pałace i ogrody w obydwu wymienionych miastach, słudzy zaś, których było siedmiu, po 10 tys. każdy. Znamienny jest komentarz, który zamieszczono w kronice poniżej wspomnianego testamentu:

O Dobry Boże, jakież to bogactwo! Jednak ów nieszczęśnik pozbawiony skarbu prawdziwej wiary na wieczność pozostanie jako największy biedak we władaniu Księcia Ciemności. Ty daj nam prawdziwe bogactwa - Twoje święte cnoty, które oby pozostały z nami teraz i na wieki ${ }^{25}$.

Jak widać, nie znalazły się tam żadne słowa pochwały czy poparcia, tylko zazdrość i potępienie. Niestety, nic więcej nie wiadomo na temat jakichkolwiek powiązań między poznańskimi karmelitami a portugalskimi Żydami mieszkającymi w Niderlandach.

W omawianych kronikach można również wyczytać wzmianki o rodzimych żydowskich kupcach, którzy handlowali w pobliżu kościoła, jak np. w Poznaniu. 18 grudnia 1764 r. za zgodą prowincjała karmelitów trzewiczkowych o. Konstantyna od św. Wawrzyńca burgrabia wspomnianego miasta, Kazimierz Miedźwiecki ${ }^{26}$, zawarł z Żydami kontrakt, na mocy którego mogli oni prowadzić handel pod dachem naprzeciwko kościoła Przenajświętszej Krwi Chrystusa w zamian za coroczną daninę w postaci kamienia stopionego łoju przekazywanego tymże karmelitom przez każdego z żydowskich kupców w dniu Wszystkich Świętych. W przypadku zaniechania tych podarunków miano Żydom zakazać handlu w tym miejscu. 23 marca 1768 r. świadczenie to zamieniono na dwa dukaty z przeznaczeniem na oświetlenie kościoła, płacone - jeden w marcu, drugi we wrześniu ${ }^{27}$.

W różnych kronikach przewijają się także informacje o poszczególnych rzemieślnikach, dzierżawcach i medykach żydowskich, z którymi zakonnice i mnisi mieli do czynienia. Występują wśród nich np. rymarze, murarze i arendarze w Poznaniu, szynkarze w Grodnie czy arendarze browaru ze słodownią, spichlerzem i wołownią w Rozkopaczewie (w powiecie

${ }^{25}$ Kronika poznańskich Karmelitów Bosych..., s. 306.

${ }^{26}$ Przy okazji warto dodać, że tenże burgrabia przetłumaczył na język polski pracę Tomasza Tretera o trzech hostiach i księgę dotyczącą cudów w kościele Bożego Ciała w Poznaniu. Kroniczka rezydencji Karmelitów..., s. 191, przyp. 77.

27 Tamże, s. 40, 106, 128, 148, 186. 
lubartowskim) w dobrach bernardynek lubelskich ${ }^{28}$. Z usług żydowskich karczmarzy duchowni byli zmuszeni korzystać też w podróży. Ciekawy opis noclegu w austerii pochodzi z kroniki klasztoru karmelitanek bosych w Lublinie. W połowie września 1655 r. siostry, które wcześniej już przyjechały z Litwy, uciekały przed nawałą rosyjsko-kozacko-szwedzką, kierując się na Kraków. Pierwszy nocleg miały w starej karczmie w Abramowicach pod Lublinem, którą później tak opisały: „,stanęliśmy u Żyda w tak ciasnej izdebce, co kiedyśmy się pokładli, to nie było kędy się obrócić, bo prawie jedna drugiej leżała na nogach. I w inszych noclegach barzo bywały miejsca szpetne, pełno wszach, żab, świrców [świerszczy], aż siostrom po głowach i gębach skakały”, [...] „,co po naszych świeżo opuszczonych celkach musiała nam być rzecz przykra"29.

Osoby konsekrowane nie obawiały się też zatrudniać wyznawców judaizmu do różnych posług w klasztorze i w jego dobrach. Przykładowo: 6 listopada 1729 r. ksieni i autorka kroniki sióstr norbertanek imbramowickich wynajęła do zrobienia okien w nowym domu w folwarku klasztornym w Trzyciążu (w powiecie olkuskim) żydowskich szklarzy z Wolbromia ${ }^{30}$. Jezuitów i karmelitanki bose odwiedzali w Poznaniu tamtejsi żydowscy lekarze. W grudniu 1647 r. oficjał i ekonom diecezji wielkopolskiej, niejaki Branecki, przysłał do rektora jezuitów poznańskich swego prezbitera z żądaniem wydania tych z grona ojców, którzy utrzymywali przyjazne stosunki z nieznanym z imienia żydowskim medykiem, ponieważ czynili to wbrew bulli papieża Grzegorza XIII. Odpowiedziano mu, ,że nie można żądać od tych osób publicznego rachunku sumienia i wymierzać im kary, jak to się dzieje w przypadku tych, którzy stają na sądzie sumienia w sakramencie pokuty, a poza tym nie można powoływać się na kazus bulli, gdyż chodzi o tzw. grzech zastrzeżony" ${ }^{\text {31 }}$. O tym, że tego typu kontakty polskiego kleru nie były odosobnione, świadczy kolejny podobny przykład, także z Poznania. Z żywota karmelitanki bosej Barbary od Najświętszego Sakramentu, czyli Teofili z Kretkowskich Zadzikowej (1609-1670), spisanego przez zakonnicę tegoż zakonu, Konstancję Iżycką, można się dowiedzieć, że w ostatnich dniach życia odwiedzał ją żydowski medyk z Poznania, który

${ }^{28}$ Tamże, s. 69, 158-159; Dzieje kapitularne zakonnic świętej matki Brygitty..., s. 202; Kronika bernardynek lubelskich..., s. 126, 135, 207.

${ }^{29}$ Kronika Klasztoru Karmelitanek Bosych..., s. 105-106, 109.

${ }^{30}$ Grothówna, Kronika..., s. 225.

${ }^{31}$ Kronika jezuitów poznańskich..., s. 430-431. 
za swoją opiekę lekarską nie brał pieniędzy i „czynił pilność koło matki zdrowia, jako ociec własny"32.

Klasztory ponadto lokowały swoje pieniądze na różnych synagogach na tzw. wyderkaf, co w rzeczywistości było ukrytą formą pożyczki dla Żydów na z góry ustalony procent. Żydzi chętnie pożyczali pieniądze od instytucji kościelnych, ponieważ w porównaniu z trudno dostępnym kredytem na wolnym rynku tam po prostu oferowano go taniej ${ }^{33}$ - co zdaje się potwierdzać kronika bernardynek wileńskich. Przykładowo: 25 października 1694 r. siostry ulokowały na kahale wileńskim 6000 złp, które zapisał im Józef Hliniecki, wojski starodubowski, zapewne na $7 \%$ według „,zwyczaju kościelnego". W 1725 r. pożyczka ta wzrosła do 8600 złp, z której to kwoty aż do 1765 r. bernardynki pobierały od Żydów jedynie 3,5\% prowizji, czyli 122 złp i 11 gr. ${ }^{34}$ Podobnie sytuacja wyglądała w Poznaniu. W 1680 r. bliżej nieznany szlachcic Noskowski ulokował u Żydów w Poznaniu 1000 złp, które legował na rzecz tamtejszego klasztoru reformatów. Pieniądze te jednak z powodu pilnej potrzeby zostały od razu wypłacone przez Żydów gwardianowi tegoż klasztoru ${ }^{35}$. Także o. Arnold, syndyk prowincji wielkopolskiej karmelitów trzewiczkowych, zapisał w 1762 r.: „1) na synagodze poznańskiej 570 florenów, 2) na kamienicy niewiernego Prochownika 900, czyli 50 dukatów, 3) dochód z sumy 1500 florenów, z której kupiec żydowski corocznie wpłaca 100 florenów"36. Wreszcie klaryski krakowskie od 1768 r. pobierały wyderkaf z zapisu 1000 złp legowanego na kahale pińczowskim. W 1800 r. okazało się, że dokumenty dotyczące tej sprawy zaginęły $^{37}$.

\section{Relacje o innych wydarzeniach}

Co istotne, w opisywanych kronikach można znaleźć także wiele różnych wiadomości z zakresu ogólnych ważnych wydarzeń, które miały miejsce w siedzibie danego klasztoru lub też poza nim, takich jak: kataklizmy,

${ }^{32}$ Karolina Targosz, Piórem zakonnicy. Kronikarki w Polsce XVII w. o swoich zakonach i swoich czasach, Kraków 2002, s. 112, 114.

${ }_{33}$ Zob. np. Stefan Gąsiorowski, Wierzytelności dominikanów lwowskich u Żydów z terenu Rusi Czerwonej w 2. połowie XVII i w XVIII wieku, [w:] Dominikanie na ziemiach polskich w epoce nowożytnej, red. Anna Markiewicz, Marek Miławicki, Kraków 2009, s. 193-213.

${ }^{34}$ Kronika bernardynek świętomichalskich..., s. 397.

${ }_{35}$ Kronika Reformatów poznańskich..., s. 134.

${ }^{36}$ Kroniczka rezydencji Karmelitów..., s. 27-28.

${ }^{37}$ Akta klasztoru pp. Franciszkanek..., s. 14. 
zbrodnie, pobicia, zuchwałe kradzieże, przechody obcych wojsk i kontrybucje. W kronikach klasztorów poznańskich kilkakrotnie pojawiają się relacje o pożarach w tym mieście, a szczególnie w kwartałach żydowskich. Przykładowo 10 czerwca 1590 r., jak napisali jezuici: „wskutek lekkomyślności Żydów spłonęła [...] prawie trzecia część miasta. Zgorzały wszystkie domy żydowskie, a przy tym jeszcze 73 domostwa chrześcijan"38. Z kolei 1 czerwca 1763 r. według kronikarza bernardyńskiego z Poznania: „miasto Kobylin [w powiecie krotoszyńskim] spłonęło ogniem z akatolickimi Żydami i ich bóżnicą, podczas gdy domy katolików były nietknięte"39. Pożar, który szalał ponownie w Poznaniu w nocy z 3 na 4 sierpnia 1764 r., został opisany w dwóch kronikach. W wersji bernardyńskiej donoszono, że:

o północy w dniu 4 sierpnia wybuchnął ogień na Żydowskiej ulicy i w przeciągu 6 godzin obrócił w perzynę 76 kamienic. Zgorzały trzy bożnice żydowskie i wielu Żydów częścią się spaliło, częścią, ratując swój dobytek, gruzami walących się domów przygniecionych zostało. Pożar zniszczyłby był całe miasto, albowiem olej, łój $\mathrm{i}$ inne palne materyały podsycały go niezmiernie, gdyby się był wiatr na Grochowe Łąki nie obrócił ${ }^{40}$.

\section{W wersji karmelickiej zaś można przeczytać:}

3 sierpnia, w nocy, po godzinie 11, wybuchł wielki pożar na ulicy Żydowskiej. Powodem pożaru była nieroztropna wiara Żydów, którym nie wolno gasić zapalonych świec szabasowych. Ogień pochłonął ponad 200 kamienic i domów drewnianych oraz dwie synagogi. W wielkim niebezpieczeństwie był kościół i klasztor Przewielebnych ojców dominikanów, z powodu silnego wiatru, przenoszącego w ich stronę płomienie. Żydzi z okazji dnia szabatu nie udzielili żadnej pomocy przy gaszeniu ognia, poza nielicznymi, których zmusili do tego żołnierze; ratowali zaś jedynie swój dobytek. Po pożarze niektórzy pozostali w Poznaniu, znalazłszy pomoc u chrześcijan, lecz bardzo wielu rozproszyło się po przedmieściach, sąsiednich miasteczkach i wsiach ${ }^{41}$.

Wydaje się, że kronika karmelitów trzewiczkowych w opisie tego wydarzenia jest bardziej wiarygodna od wcześniejszej, bogata w szczegóły i - być może - naoczne spostrzeżenia z tej racji, że ich poznańska rezydencja, jak wiadomo, mieściła się właśnie przy ulicy Żydowskiej. Znajdujemy w niej nie tylko suchą relację z pożogi, lecz także wskazanie na jej przyczyny i opis losów pogorzelców.

\footnotetext{
${ }^{38}$ Kronika jezuitów poznańskich..., s. 97.

39 Jan Kamieński, [Kronika poznańska], [w:] Kroniki Bernardynów poznańskich..., s. 284.

${ }^{40}$ Zaginiony rękopis kroniki domowej..., s. 370.

${ }^{41}$ Kroniczka rezydencji Karmelitów..., s. 34-35.
} 
Ciekawe uwagi dotyczące spraw ogniowych i Żydów można znaleźć też w dalszej części tej kroniki. Otóż już we wrześniu w tym samym 1764 r. wybuchły kolejne dwa pożary na ulicy Żydowskiej. Natomiast 19 lipca roku następnego Wawrzyniec Pachurski, jeden z mieszkańców przedmieścia św. Wojciecha, przyczynił się do ugaszenia ognia w mieszkaniu pewnej rodziny żydowskiej podczas wieczerzy szabatowej. Ci bowiem nie chcieli sami zapobiec katastrofie „z powodu swej czczej praktyki” i jego wezwali na pomoc, „obiecując mu nagrodę"42. Odmienne natomiast wydarzenie było na ulicy Żydowskiej w Poznaniu 17 października 1766 r. około godziny piątej po południu. Wówczas ,naprzeciw synagog, w nowo odbudowanym po wielkim pożarze domu, zapalił się komin. Ze względu zaś na bliski szabat, dzięki staraniu [...] Żydów, którzy tłumnie nadbiegli z wodą, ogień ugaszono"43. Jak opisano w tejże kronice, dalsze zmagania z żywiołem ognia były udziałem poznańskich Żydów 8 i 16 listopada 1766 r. oraz 17 i 18 kwietnia roku następnego. Straty chrześcijan w tych i innych pożarach także były wysokie, co skłoniło wreszcie miejskiego instygatora (prawdopodobnie Dionizego Szperna) do zorganizowania inspekcji złożonej z dwóch chrześcijańskich mistrzów ciesielskich i murarskich oraz dwóch Żydów, którzy gdzie tylko zauważyli niebezpieczeństwo pożaru, nakazywali zburzyć komin. „Jeśli zaś w kominie widać było jakoweś belki, natychmiast były usuwane przez rzemieślników, a kominy dla bezpieczeństwa polecano naprawić i wyczyścić, pod groźbą z całą powagą orzeczonej i ogłoszonej kary dla opornych" ${ }^{44}$. Te słuszne zabiegi nie zlikwidowały jednak dalszych ogniowych niebezpieczeństw, ponieważ z powodu ludzkich błędów doszło do kolejnych pożarów 9 i 10 kwietnia 1768 r., a także 13 grudnia roku następnego ${ }^{45}$.

Żydowską dzielnicę w Poznaniu nękały także inne kataklizmy, jak powodzie, a od połowy 1768 r. - przechody rosyjskich wojsk, które żądały żywności, wolnych kwater, wysokich kontrybucji i rozrywki. Żołnierze rujnowali finansowo i grabili całe miasto. Jednak magistrat, jak o tym można przeczytać w opisywanej kronice, nie podjął żadnych środków zaradczych. Dopiero 11 lipca 1768 r. miejscowi Żydzi wynajęli około 15 ludzi, w tym chrześcijan i Żydów, którzy patrolowali ulice, dbając o porządek, dzięki czemu także i kościół karmelitów trzewiczkowych „był zabezpieczony przed

\footnotetext{
42 Tamże, s. 49.

43 Tamże, s. 80.

44 Tamże, s. 81, 82, 92, 93, 109.

45 Tamże, s. 130-131, 185.
} 
rabusiami”" ${ }^{\prime 4}$. Niestety, pustki w kasie kahalnej spowodowały zaległości w opłacie podatków i szafarz miejski zamknął 8 listopada 1768 r. Żydom, a przy okazji także karmelitom, dopływ wody. Jej dystrybucję przywrócono dwa dni później - po spłaceniu należności przez gminę żydowską ${ }^{47}$.

Kroniki klasztorne skwapliwie informują też o wszelkich powiązanych z Żydami morderstwach, bójkach i kradzieżach. Do masowych zbrodni na Żydach miało dojść, jak opisał Jan z Komorowa w kronice braci mniejszych, gdy pod koniec XV w. legat papieski ogłosił krucjatę przeciwko Turkom i innym niewiernym. W Krakowie wielu wyznawców judaizmu zabili wówczas krzyżowcy. Wtedy król Jan Olbracht zezwolił Żydom mieszkać w Kazimierzu pod Krakowem ${ }^{48}$. Niepotwierdzone w innych źródłach są też zapiski z kroniki bernardynów poznańskich, w której pod rokiem 1744 można przeczytać o wielkim powstaniu chłopskim na Litwie. Jego przywódca, niejaki Wosczyło, miał podburzyć katolickie pospólstwo przeciwko Żydom, którzy gnębili chłopów daninami, pracując jako arendarze magnaccy. Pięć tysięcy chłopów miało utopić i w inny sposób pozabijać dwa tysiące Żydów. Pogromy te powstrzymali dopiero żołnierze Rzeczypospolitej, którzy „chłopów rozbili i pokarali”‘9.

Z kolei w kronice jezuitów poznańskich zachował się pod rokiem 1572 zapis o jakimś niewymienionym z nazwiska współbracie, który podczas kazania bezpodstawnie oskarżył Żydów o „haniebną zbrodnię”, co spotkało się z ostrą reakcją miejscowych rajców, ponieważ nie było to pierwsze jego „wyssane z palca” pomówienie. Władze klasztorne pouczyły go więc, ,aby w przyszłości nie ważył się więcej na tego rodzaju wystąpienia, póki nie nabierze pewności, a potem nie zbada sprawy wnikliwie razem z tymi, których rzecz dotyczy"50. Znacznie poważniejsze wydarzenie natury kryminalnej, które miało miejsce w dobrach wojewody smoleńskiego Piotra Sapiehy (1701-1771), opisano w kronice bernardynów poznańskich. W sierpniu 1763 r. trzej Żydzi i jedna Żydówka zabili tam w ogrodzie w okrutny sposób szesnastoletnią dziewczynę. Wszystkich złapano i poddano postępowaniu sądowemu. Dwaj Żydzi i Żydówka zostali ochrzczeni i skazani na śmierć, a po jej wykonaniu „ze czcią pochowani”. Trzeci Żyd zmarł w swej wierze jeszcze w więzieniu, zapewne w wyniku tortur. Następnie „był koniem ciągniony po ulicach obok bóżnicy Żydom

46 Tamże, s. 135, 136, 138, 140, 141, 143, 158, 160, 167, 183.

47 Tamże, s. 151.

48 Jan z Komorowa, Krótka Kronika Zakonu Braci Mniejszych. Cz. 2..., s. 558-559.

49 Zaginiony rękopis kroniki domowej..., s. 364.

${ }^{50}$ Kronika jezuitów poznańskich..., s. 19-20. 
na urągowisko, [po czym] poza miastem na miejscu stracenia zostawiony bez pogrzebu" ${ }^{51}$.

Informacje o bójkach między chrześcijanami a Żydami pojawiają się wyłącznie w kronice jezuitów z Poznania, która dotyczy lat 1570-1653. W tym okresie odnotowano sześć tego typu zdarzeń. Jakkolwiek to właśnie jezuitów często pomawiano o podburzanie uczniów ich szkół przeciwko innowiercom, ci zazwyczaj bagatelizowali takie oskarżenia. Przykładowo: 3 sierpnia 1575 r. podczas procesu pewnego syna mieszczanina poznańskiego, scholara, który pobił Żyda i z polecenia burmistrza Poznania, Stanisława Brzeźnickiego, został uwięziony, a następnie postawiony przed sądem w ratuszu, rektor jezuitów poprosił Radę Miejską, aby w przyszłości tego rodzaju błahe występki studentów można było rozpatrywać w kolegium. „A jeśli już doszłoby przypadkiem do poważniejszego zajścia, wobec którego kary szkolne okazałyby się niewystarczające, wówczas sprawę dla szlachcica rozstrzygałby starosta, a dla plebejusza Rada Miejska" ${ }^{52}$. Stwierdził też, że takie postępowanie władz miejskich „odbiera studentom swobodę i przywileje, a na dwór biskupi ściąga gwałtowne i niesprawiedliwe ataki”, słowem - „nie pochwalał uczynku burmistrza”. „Ten ostatni zaś, czerwieniąc się ze wstydu za swoją porywczość, przyrzekł, że na przyszłość będzie dla studentów łagodniejszy"53. Jednakże dowodem na to, że bójki z Żydami były inicjowane przez uczniów jezuickich, mogą być - przytoczone w omawianej kronice - słowa wojewody Stanisława Górki, który $\mathrm{w}$ dniu uroczystej inauguracji swojego urzędowania w Poznaniu 20 czerwca 1576 r. przy powitaniu powiedział jezuitom, aby „powściągali młodzież od atakowania Żydów, gdyż poruczono mu opiekę nad nimi”"54.

Ostrzeżenia te na nic się jednak nie zdały, ponieważ uczniowie szkół jezuickich wszczynali regularne bijatyki z Żydami, zwane też tumultami, które były m.in. 24 czerwca roku $1579^{55}$, 24 sierpnia $1601^{56}, 21$ kwietnia $1626^{57}$ i $24-25$ maja $1628^{58}$. Czasami jezuitom udawało się jednak powstrzymywać swoich studentów przed udziałem w tego typu zajściach, co zdarzyło się np. 7 sierpnia 1618 r., kiedy Żydzi wyrządzili krzywdę malarzowi, „który

${ }^{51}$ Kamieński, [Kronika poznańska]..., s. 284.

${ }^{52}$ Kronika jezuitów poznańskich..., s. 32.

${ }^{53}$ Tamże.

54 Tamże, s. 39.

55 Tamże, s. 52-53.

56 Tamże, s. 140.

57 Tamże, s. 314.

58 Tamże, s. 326. 
na fasadzie ratusza wymalował czyhającego nań Żyda" ${ }^{59}$, i w odwecie zostali zaatakowani przez pospólstwo, a także 31 lipca 1639 r., gdy napadnięto na Żydów podczas procesji do kościoła dominikanów ${ }^{60}$. Z uwagi jednak na wcześniejsze burdy biskupi i władze miejskie stale o napaść na Żydów oskarżali jezuitów i ich scholarów ${ }^{61}$.

Innymi spektakularnymi wydarzeniami odnotowywanymi w kronikach klasztornych były kradzieże dotyczące dóbr zakonnych. Do szczególnie zuchwałych należały te, które odnosiły się do sprzętów liturgicznych. Aż dwie kroniki poznańskie - bernardynów i karmelitów bosych - odnotowały taką właśnie kradzież z kościoła w miejscowości Zakrzewo w diecezji płockiej ${ }^{62}$ w 1739 r. Łupem złodzieja, nieznanego z imienia Żyda z Sierpca, padła puszka z Najświętszym Sakramentem i inne srebrne przedmioty ofiarowane kościołowi przez wiernych. Hostię, która znajdowała się w puszce, miał on sprzedać za jednego tynfa współwyznawcom w Sierpcu. Gdy wieść o kradzieży się rozeszła, złodziej zbiegł w niewiadomym kierunku. Sprawa ta trafiła przed Trybunał Koronny w Piotrkowie, który wobec nieobecności sprawcy rozkazał zburzyć jego dom, a na jego miejscu postawić murowaną kolumnę. Na jej szczycie miano umieścić kielich z wyobrażeniem hostii i inskrypcją „Wyruszyłem przeciwko temu miejscu, aby je spustoszyć” (2 Krl 18, 25), na jej środku - sentencję „Uczcie się sprawiedliwości i nie lekceważcie Świętych” oraz napis w języku łacińskim i po polsku:

Tu miejsce strasznej zbrodni, tu płakać w przemiany

Bóg nieoszacowany za tynfa przedany.

$\mathrm{Z}$ dekretu trybunału o tak straszną winę

Dom z ziemią porównany poniósł tę ruinę.

Tak słuszna, że nie mogła upaść w sądach sprawa

Zwycięskich w obalinach w Sierpcu kolos stawa ${ }^{63}$.

59 Tamże, s. 286.

${ }^{60}$ Tamże, s. 388.

${ }^{61}$ Tamże, s. 286, 388.

${ }^{62} \mathrm{~W}$ kronikach występują dwie różne nazwy miejscowości, gdzie dopuszczono się kradzieży: Jerzewo w kronice karmelitów bosych i Zakrzewo w kronice bernardynów. Pierwsza z tych miejscowości znajduje się w powiecie łowickim w obecnym województwie łódzkim i prawdopodobnie jest mylna. W kwestii zaś drugiej istnieje problem, ponieważ są cztery miejscowości o tej nazwie w pobliżu miasta Sierpc, skąd pochodził złodziej; dwie z nich znajdują się w powiecie płockim (Zakrzewo i Zakrzewo Kościelne) oraz po jednej w powiecie lipnowskim i włocławskim. W obrębie diecezji płockiej jest znacznie więcej miejscowości o nazwie Zakrzewo. Ustalenie właściwej lokalizacji zdarzenia wymaga dalszych badań.

${ }^{63}$ Zaginiony rękopis kroniki domowej..., s. 363; Kronika poznańskich Karmelitów Bosych..., s. 249. 
W kronikach nie napisano, czy faktycznie wykonano ten trybunalski wyrok i kto miał dać na ten cel pieniądze. Rozwiązania tego problemu należy zapewne szukać w innych zachowanych źródłach dotyczących miasta Sierpca z tej epoki.

Żydzi pojawiają się w dalszych zapiskach różnych kronik klasztornych dotyczących kradzieży, nie zawsze jednak w charakterze sprawców. Czasem występują jako podejrzani, innym razem jako paserzy, a także jako ofiary lub pomocnicy w łapaniu złodziei ${ }^{64}$. Zupełnie kuriozalna jest wzmianka w kronice benedyktynek poznańskich, według której w 1636 r. pewien Żyd został okradziony w Poznaniu przez błąkającego się po śmierci, podobnego do mnicha, „ducha Bartosza organisty”. Po pewnym czasie rzeczony duch zwrócił pieniądze wprost do domu tegoż Żyda, wrzucając je przez komin i przy okazji raniąc gospodarza ${ }^{65}$.

Przez karty kronik klasztornych przewijają się również wzmianki, w których Żydzi są odnotowywani jedynie jako widzowie czy uczestnicy jakichś wydarzeń ${ }^{66}$, oraz ogólne informacje odnoszące się do usytuowania budynków (w tym synagog), ulic i cmentarzy żydowskich ${ }^{67}$.

Co ciekawe, w przejrzanych kronikach Żydzi występują zwykle jako zbiorowość. Rzadko wymienia się ich z imienia, chyba że dotyczy to neofitów, których miano się podaje, zazwyczaj jednak już po chrzcie. W dwóch kronikach został wymieniony Abraham Ezofowicz, lecz jako podskarbi - bez żadnych konotacji z wyznawcami judaizmu ${ }^{68}$. W kronikach fraza „uczciwy Żyd” prawie nie gości, jakkolwiek w jednej z nich opisano, jak w 1773 r. Żydzi w Kostrzynie donieśli władzom na ubogą kobietę, która chciała im sprzedać dziecko za dwa złote ${ }^{69}$. Z zapisków jezuitów można się natomiast dowiedzieć, że zakonnicy ci w latach 1598-1614 uczyli w kolegium poznańskim podstaw języka hebrajskiego ${ }^{70}$.

${ }^{64}$ Lata 1636, 1719, 1766, 1768-1769. Kronika benedyktynek poznańskich, [w:] Kroniki Benedyktynek poznańskich..., s. 88-89; Młodsza kronika zakonna benedyktynek poznańskich, [w:] Kroniki Benedyktynek poznańskich..., s. 273; Kroniczka rezydencji Karmelitów..., s. 67, 132, 133, 159, 165.

${ }^{65}$ Kronika benedyktynek poznańskich..., s. 88-89.

${ }^{66}$ Kamieński, [Kronika poznańska]..., s. 200, 201, 213.

${ }^{67}$ Przykładowo: 1) budynki: Kroniczka rezydencji Karmelitów..., passim; 2) ulice: tamże; Kronika poznańskich Karmelitów Bosych..., s. 112; Zaginiony rękopis kroniki domowej..,, s. 356; 3) cmentarze: Kamieński, [Kronika poznańska]..., s. 199; Kroniczka rezydencji Karmelitów..., s. 74.

68 Jan z Komorowa, Krótka Kronika Zakonu Braci Mniejszych. Cz. 2.., s. 581; Z kroniki Jana Komorowskiego, [w:] Kroniki Bernardynów poznańskich..., s. 37.

${ }^{69}$ Zaginiony rękopis kroniki domowej..., s. 389; Targosz, Piórem zakonnicy..., s. 249.

${ }^{70}$ Kronika jezuitów poznańskich..., s. 127, 237. 
W omawianych źródłach określa się Żydów jako niewiernych czy złośliwych i umieszcza w zestawieniu obok heretyków i pogan ${ }^{71}$. To tylko - jak donoszą karmelici - król szwedzki Karol Gustaw, bawiący w 1655 r. w Prusach, mógł żartobliwie pomylić z Żydem jednego z ich mnichów przebranego w związku z tajną misją za górala ${ }^{72}$. Mimo że wraz z innymi mieszkańcami Rzeczypospolitej Żydzi z rozkazu dowódców wojsk rosyjskich czy pruskich podlegali grabieżom, konfiskatom, kontrybucjom i wysiedleniom, w kilku kronikach odnoszących się do okresu II połowy XVIII w. pomawiano ich o współpracę z najeźdźcami i chęć poddaństwa. Na przykład bernardyński kronikarz z Poznania donosił w swym dziele pod rokiem 1763, że Żydzi w mieście „wystawili publicznie w bóżnicy obraz króla pruskiego z napisem: Fryderyk II pobożny, szczęśliwy, ojciec ojczyzny, obrońca pokoju itd., niech żyje i kwitnie, i pieśń śpiewali z takim wierszem: Po podziale Polski wojna ustanie"73. Z kolei według innego kronikarza, karmelity tamtejszego, w listopadzie 1767 r. Żydzi z Małopolski zamierzali podstępnie wywieźć do Wrocławia duże pieniądze w srebrze niebędące w obiegu. Zostały one przejęte „przez strażników Skarbu Królestwa” w Zbąszyniu, a ich wartość oszacowano na 115 tys. florenów polskich. Po opieczętowaniu przewieziono je do Poznania z zamiarem wysłania do Warszawy i przekazania do skarbu królewskiego ${ }^{74}$.

\section{Podsumowanie}

Jaki więc obraz Żydów znajdujemy w zaprezentowanych źródłach? Wydaje się, że autorów kronik klasztornych Żydzi interesowali przede wszystkim jako konwertyci, choć zdarzało się również, że pomawiano ich o chęć nawrócenia chrześcijan na judaizm. Naciski na te żydowskie konwersje pojawiały się zaś często przy okazji bardzo nagłaśnianych przez Kościół rzekomych profanacji hostii i mordów rytualnych. Najwięcej tego typu zdarzeń można było dostrzec w Poznaniu. Nieco mniej miejsca w klasztornych relacjach zajmują informacje dotyczące, jak się można spodziewać, zwykłych kontaktów między władzami klasztornymi a żydowskimi kontrahentami, kupcami, dzierżawcami, rzemieślnikami, dłużnikami i medykami. W opisach ważnych dla danego klasztoru czy miasta wydarzeń

\footnotetext{
${ }^{71}$ Dzieje kapitularne zakonnic świętej matki Brygitty..., s. 62.

72 Targosz, Piórem zakonnicy..., s. 231-232.

73 Zaginiony rękopis kroniki domowej..., s. 368, 369, 385.

74 Kroniczka rezydencji Karmelitów..., s. 116.
} 
Żydzi pojawiają się jakby mimochodem - jako ci, którzy albo byli wśród ofiar zdarzeń, albo też byli sprawcami różnych kataklizmów, zbrodni, pobicia, kradzieży, kontrybucji, czasem nawet pomawiano ich o współpracę z obcymi wojskami. Częstość tego rodzaju wzmianek jest zapewne wprost proporcjonalna do procentowego udziału Żydów w ogólnej populacji danej miejscowości.

Wydaje się, że na bardziej szczegółowe analizy dotyczące przedstawionego materiału źródłowego należy poczekać aż do czasu przejrzenia wszystkich dostępnych kronik klasztornych z okresu staropolskiego. Dopiero wówczas będzie się można pokusić o wskazanie konkretnych zależności związanych z powstaniem danej notatki odnoszącej się do Żydów czy innych mniejszości religijnych i spróbować wysnuć daleko idące wnioski czy konotacje terytorialne.

Podsumowując, należy stwierdzić, że kroniki klasztorne z czasów dawnej Rzeczypospolitej stanowią bardzo cenne źródło dotyczące nie tylko historii poszczególnych zakonów czy duchowieństwa polskiego, ale także dziejów mentalności, życia codziennego i mniejszości religijno-etnicznych. Mimo iż tematyka judaistyczna pojawia się w tego typu kronikach zazwyczaj sporadycznie, jest ona bardzo różnorodna, dotyka bowiem prawie wszystkich obszarów działalności Żydów w Polsce i za granicą. Może też być ona wspaniałym dopełnieniem innych źródeł z tego zakresu, w tym proweniencji żydowskiej oraz różnych instytucji i urzędów świeckich. Trzeba jednak zwrócić uwagę, że wiarygodność informacji zawartych w kronikach klasztornych jest zawsze uzależniona od odległości w czasie i przestrzeni od opisywanych przez danego kronikarza wydarzeń, które w miarę możliwości powinny być weryfikowane z innymi przekazami źródłowymi z danej epoki.

Stefan Gasiorowski Uniwersytet Jagielloński, PAN st.gasiorowski@uj.edu.pl 
